\title{
Development of new preclinical models to advance adrenocortical carcinoma research
}

\author{
Katja Kiseljak-Vassiliades'1,2, Yu Zhang', Stacey M Bagby³, Adwitiya Kar', Nikita Pozdeyev', Mei Xu1, \\ Katherine Gowan4, Vibha Sharma', Christopher D Raeburn5, Maria Albuja-Cruz5, Kenneth L Jones ${ }^{4}$, \\ Lauren Fishbein 1,2, Rebecca E Schweppe1, Hilary Somerset6, Todd M Pitts 3 , Stephen Leong ${ }^{3}$ and \\ Margaret E Wierman1,2
}

1Division of Endocrinology, Metabolism and Diabetes, University of Colorado School of Medicine, Aurora, Colorado, USA 2Research Service Veterans Affairs Medical Center, Denver, Colorado, USA

${ }^{3}$ Division of Medical Oncology, Department of Medicine, University of Colorado School of Medicine, Aurora, Colorado, USA ${ }^{4}$ Department of Pediatrics, University of Colorado School of Medicine, Aurora, Colorado, USA ${ }^{5}$ Department of Surgery, University of Colorado School of Medicine, Aurora, Colorado, USA

${ }^{6}$ Department of Pathology; University of Colorado School of Medicine, Aurora, Colorado, USA

Correspondence should be addressed to M E Wierman or K Kiseljak-Vassiliades: margaret.wierman@ucdenver.edu or katja.kiseljak-vassiliades@ ucdenver.edu

\begin{abstract}
Adrenocortical cancer (ACC) is an orphan malignancy that results in heterogeneous clinical phenotypes and molecular genotypes. There are no curative treatments for this deadly cancer with $35 \%$ survival at five years. Our understanding of the underlying pathobiology and our ability to test novel therapeutic targets has been limited due to the lack of preclinical models. Here, we report the establishment of two new ACC cell lines and corresponding patient-derived xenograft (PDX) models. CU-ACC1 cell line and PDX were derived from a perinephric metastasis in a patient whose primary tumor secreted aldosterone. CU-ACC2 cell line and PDX were derived from a liver metastasis in a patient with Lynch syndrome. Short tandem repeat profiling confirmed consistent matches between human samples and models. Both exomic and RNA sequencing profiling were performed on the patient samples and the models, and hormonal secretion was evaluated in the new cell lines. RNA sequencing and immunohistochemistry confirmed the expression of adrenal cortex markers in the PDXs and human tumors. The new cell lines replicate two of the known genetic models of ACC. CU-ACC1 cells had a mutation in CTNNB1 and secreted cortisol but not aldosterone. CU-ACC2 cells had a TP53 mutation and loss of MSH2 consistent with the patient's known germline mutation causing Lynch syndrome. Both cell lines can be transfected and transduced with similar growth rates. These new preclinical models of ACC significantly advance the field by allowing investigation of underlying molecular mechanisms of ACC and the ability to test patient-specific therapeutic targets.
\end{abstract}
Key Words
- adrenocortical carcinoma
cell lines
- patient-derived xenografts
- hyperaldosteronism
- Lynch syndrome

Endocrine-Related Cancer (2018) 25, 437-451

\section{Introduction}

Our understanding of the underlying mechanisms driving adrenal carcinogenesis and the ability to develop new treatment options for patients has been severely limited by the lack of in vitro and animal models. Whereas benign incidental adrenal adenomas are common, occurring in up to $4-7 \%$ of patients, adrenocortical carcinoma (ACC) 
is an uncommon, aggressive cancer occurring in 0.7-2 per million people (Allolio \& Fassnacht 2006, Else 2014). Adrenocortical carcinoma has a female predominance, occurring in two peaks, one in children and the other in young and older adults, with a median age at diagnosis of 42.6 years (Young et al. 2007, Else et al. 2014). ACC has a poor prognosis with the majority of patients having regional or distant metastases at time of diagnosis (Allolio \& Fassnacht 2006). Surgery is the primary therapy; however, many tumors are not surgically resectable and most will reoccur (Grubbs et al. 2010). Mitotane (OPDDT), an adrenally toxic insecticide derivative, remains the only FDA-approved therapy and the main chemotherapeutic agent used in ACC, but it has significant toxicities and many patients do not maintain therapeutic levels (Terzolo et al. 2007, Berruti et al. 2017). Standard chemotherapy with EDP (etoposide, doxorubicin and cisplatin) for advanced disease has limited effectiveness (Fassnacht et al. 2012). Tragically, the overall survival is $<35 \%$ at 5 years (Else et al. 2014).

The mechanisms underlying ACC tumorigenesis are poorly understood. Patients with genetic syndromes such as Li-Fraumeni (loss of TP53) (3-7\% of ACC), BeckwithWiedmann syndrome (chromosome 11 defects) $(<1 \%$ of ACC) and Lynch syndrome (defects in mismatch repair genes) (3\% of ACC) are at a higher risk of developing ACC (Else 2012, Raymond et al. 2013). However, the majority of ACC are sporadic. Approximately $40 \%$ of ACC tumors show activation of the $\beta$-catenin and canonical Wnt pathways and $20 \%$ of tumors have a mutation in TP53 (Assie et al. 2014, Zheng et al. 2016). The remainder have unknown drivers. To date, none of the known pathways have been successfully targeted (Gross et al. 2006, Quinkler et al. 2008, Adam et al. 2010, Haluska et al. 2010, Wortmann et al. 2010, Berruti et al. 2012, Weigel et al. 2014, Fassnacht et al. 2015).

Clinicians caring for these patients have been impressed by the diversity of phenotype, genotype and progression of the disease. The recent publications of by European Network for the Study of Adrenal tumors (ENSAT) and The Cancer Genome Atlas (TCGA) consortiums have given insight into the genetic and genomic landscape of adrenocortical cancers (Assie et al. 2014, Zheng et al. 2016). Specific molecular subtypes of ACC tumors exist with high mutational rates, chromosomal duplications and mutations in TP53 or in genes in the Wnt/ $\beta$-catenin pathways that portend poor prognosis (Assie et al. 2014, Zheng et al. 2016). However, in another subset (about $30-40 \%)$, oncogenic drivers were not identified. With the expanded categorization of tumor subtypes, models to explore underlying pathways to tumorigenesis and new therapeutic targets are needed.

Over the past 30 years, multiple attempts to derive ACC cell lines and animal models have been performed. The predominant ACC cell line used in research efforts has been the $\mathrm{H} 295$ cells, first established in 1980 from a primary ACC tumor (Gazdar et al. 1990) as well as the subsequent subline H295R (Rainey et al. 2004). Other putative ACC cell lines have not gained use due to the uncertainty of the source or lack of availability (Wang \& Rainey 2012). Pinto and coworkers reported a pediatric ACC PDX (SJ-ACC3) but were unable to derive a complimentary ACC cell line (Pinto et al. 2013). Hantel and coworkers recently reported the development of the first adult PDX and cell line termed MUC-1 from a supraclavicular ACC metastasis (Hantel et al. 2016). With the heterogeneity of the disease, however, additional models are needed. Based upon our prior success in creating patient-derived tumor xenografts in immunodeficient mice for a variety of cancer types (Pitts et al. 2010, Tentler et al. 2012, Bagby et al. 2016) and new approaches to tumor cell line development (Takahashi \& Yamanaka 2006, Liu et al. 2012), we utilized similar approaches to develop new preclinical ACC models.

\section{Methods}

\section{Establishment of the ACC tumor cell lines and PDX}

Patients with ACC were consented for an IRB-approved study at the University of Colorado. At the time of surgical resection, a fine-needle aspiration (FNA) of the tumor was taken with a 21-gauge needle. Cells were dispersed directly on Petri dish or on irradiated (100 Gy) feeder cells, Swiss 3T3 fibroblasts (J2 strain), monolayer in the presence of a Rho-associated protein kinase (ROCK) inhibitor, as described previously (Liu et al. 2012). Additional human ACC samples were immediately implanted subcutaneously into the bilateral flanks of five female athymic nu/nu mice each (Envigo, Indianapolis, IN, USA) (Bagby et al. 2016). CU-ACC1 PDX was re-passaged after 3 months and CU-ACC2 after 5 months. At the time of passage, a FNA biopsy of the PDX was performed, and these samples were placed on Petri dish or on the feeder cell monolayer as above for propagation of additional cell models.

\section{Cell culture}

H295R cells were a gift from W. Rainey (University of Michigan, Ann Arbor, MI, USA) and grown as described (Rainey et al. 2004). Our new ACC cell lines were grown 
in F medium (3:1 (v/v) F-12 Nutrient Mixture (Ham)Dulbecco's modified Eagle's medium (Invitrogen), 5\% fetal bovine serum, $0.4 \mu \mathrm{g} / \mathrm{mL}$ hydrocortisone (Sigma-Aldrich), $5 \mu \mathrm{g} / \mathrm{mL}$ insulin (Sigma-Aldrich), $8.4 \mathrm{ng} / \mathrm{mL}$ cholera toxin (Sigma-Aldrich), $10 \mathrm{ng} / \mathrm{mL}$ epidermal growth factor (Invitrogen) and $24 \mu \mathrm{g} / \mathrm{mL}$ adenine (Sigma-Aldrich)) with addition of $5 \mu \mathrm{mol} / \mathrm{L}$ Y-27632 (ROCK inhibitor; Enzo Life Sciences, Farmingdale, NY, USA) while on feeder cells. After 2-3 passages, the cells were passaged without the ROCK inhibitor. Media was replaced every 4-6 days.

\section{Immunohistochemistry and immunocytochemistry}

Five micron thick paraffin sections of human tumors and PDX samples were prepared for immunodetection of alpha-Inhibin (Ventana/Roche; Tuscon, AZ; \#760-2834, predilute) and MSH2 (Ventana; \#760-4265, predilute) on the Ventana Ultra autostainer under standard antigen retrieval (AR) conditions with CC1 using UltraView $\mathrm{DAB}$ polymer detection. Additional sections were deparaffinized, AR was performed and immunostained for Ki-67 (Neomarkers/Thermo Scientific; clone SP6; 1:300), p53 (Cell Marque, Rocklin, CA, USA; clone D07; 1:300), $\beta$-catenin (Cell Marque; clone 14; 1:20), Melan-A, (Agilent; clone A103; 1:10) and SF1 (Perseus Protemics, Tokyo, Japan; clone N1665; 1:100). Ki-67, p53, $\beta$-catenin and Melan-A antigens were revealed in $\mathrm{pH} 9.5$ BORG solution (Biocare Medical, Concord, CA, USA) for $10 \mathrm{~min}$ at $110^{\circ} \mathrm{C}$ (NxGen Decloaker, Biocare) with a 10-min ambient cool down. SF1 required modest retrieval in $10 \mathrm{mM}$ sodium citrate $\mathrm{pH} 6.0$ for $10 \mathrm{~min}$ at $110^{\circ} \mathrm{C}$ in the Decloaker. Immunodetection of Ki-67, p53, $\beta$-catenin and Melan-A was performed on the Benchmark XT autostainer (Ventana) with primary incubation for $32 \mathrm{~min}$ using UltraView DAB polymer detection. SF1 required standard manual detection with a $3 \%$ hydrogen peroxidase blocker for $10 \mathrm{~min}$ and $2.5 \%$ horse serum blocker for $20 \mathrm{~min}$. SF1 primary antibody was incubated overnight at $4^{\circ} \mathrm{C}$ in a humidity chamber followed by Mouse ImmPress polymer detection system (Vector Laboratories, Burlingame, CA, USA) for $30 \mathrm{~min}$. Antibody complexes were visualized with ImmPACT DAB (Vector) for $5 \mathrm{~min}$. All sections were counterstained in Harris hematoxylin for $2 \mathrm{~min}$, blued in $1 \%$ ammonium hydroxide, dehydrated in graded alcohols, cleared in xylene and coverglass-mounted using synthetic resin. Negative controls for each tissue type to confirm the specificity of the immunostaining included omission of the primary antibody incubation step and substitution of the primary antibody with nonimmune immunoglobulin of the same isotype at the same concentration as the primary antibody. All negative controls were appropriately negative.

For immunocytochemistry, cells (CU-ACC1 passage \#11 and CU-ACC2 passage \#12) were plated on poly-L-lysine-coated coverslips and fixed using $4 \%$ paraformaldehyde in PBS pH7.4 for $10 \mathrm{~min}$ at room temperature. Next, coverslips were placed in AR buffer $(100 \mathrm{mM}$ Tris, $55(\mathrm{w} / \mathrm{v})$ urea, $\mathrm{pH} 9.5)$ at $95^{\circ} \mathrm{C}$ for $10 \mathrm{~min}$ and then washed. Coverslips were then permeabilized using PBS containing 0.1\% Triton X-100, blocked with $1 \%$ BSA in PBST and placed in primary antibody at $4^{\circ} \mathrm{C}$ overnight. The following day, the coverslips were washed and incubated with the secondary antibody (Fluorescein (FITC) AffiniPure Donkey Anti-Mouse IgG $(\mathrm{H}+\mathrm{L}))$ in 1\% BSA for $1 \mathrm{~h}$ at room temperature. Coverslips were then incubated with DAPI stain and mounted on the slides. Immunocytochemistry was performed using primary antibodies: SF1 (Perseus Protemics; clone N1665; 1:50) and Ki-67 (BD Biosciences, San Jose, CA, USA; clone B56; $1: 1000)$. Negative controls to confirm the specificity of the immunostaining included omission of the primary antibody incubation step and substitution of the primary antibody with non-immune immunoglobulin of the same isotype at the same concentration as the primary antibody. All negative controls were appropriately negative.

\section{LC-MS/MS measurements of steroids}

H295R, CU-ACC1 or CU-ACC2 cells $\left(3 \times 10^{6}\right)$ were plated in 6-well plates in DMEM/F12 medium with 5\% charcoalstripped fetal bovine serum (Gibco) and 1\% PSF and $48 \mathrm{~h}$ later were either untreated or treated with $100 \mathrm{nM} \mathrm{ACTH}$, $100 \mathrm{nM}$ angiotensin or $10 \mu \mathrm{M}$ Forskolin for $24 \mathrm{~h}$. Media was collected and hormones were measured. The medium and internal standards were extracted with $3 \mathrm{~mL}$ of Methyl tert-butyl ether as previously described (Hill et al. 2010) and were run by LC/MS on a 5500 Q-TRAP, Sciex, Framingham MA mass spectrometer as described (Jantti et al. 2013). Steroid levels were normalized to cellular protein and reported as $\mathrm{ng} / \mathrm{mg}$ of protein.

\section{Short tandem repeat profiling}

DNA $(1 \mu \mathrm{g})$ from the human ACC tumors and matched blood as well as the PDX and cell lines was extracted using QIAamp DNA mini kits (Qiagen). STR profiling was performed by the Molecular Biology Service Center at the University of Colorado, using a standard technique (Reid et al. 2004). The minimum match analysis compared the 8 core STR loci and amelogenin. The authentication 
of the new preclinical models was performed against ATCC, COG cell, DSMZ and NCBI online databases. Species identification was attained using genomic DNA two-prong molecular approach as described previously (Cooper et al. 2007).

\section{Next-generation sequencing}

Total RNA from cells or tissue was extracted using TRIzol (Invitrogen) and purified with the Qiagen RNAeasy Kit (Qiagen). Genomic DNA was isolated from the patient blood samples, human and PDX tissues, and ACC cell lines (CU-AAC1 passage \#10 and CU-ACC2 passage \#10) using QIAamp DNA mini kit (Qiagen). RNA library preparation was performed using an Illumina TruSeq mRNA library kit (Illumina, San Diego, CA, USA) and the Agilent Sure Select XT6 Exome Capture Kit (Agilent Technologies). Sequencing was performed on HiSeq 4000 (Illumina). Normal adrenal RNA sequencing data were obtained from the GTEX database (phs000424.v6.p1) using dbGaP for comparison to ACC tumor RNAseq data, and batch correction was done prior to analysis. RNA reads were mapped to the human genome sequence (hg38) using GSNAP. Transcript assembly and expression were calculated by Cufflinks and analyzed for differential gene expression by ANOVA in R (Trapnell et al. 2010, Bradford et al. 2015). Whole-exome sequencing reads were mapped to the reference human genome GRCh37 (hg19) using BWA (Li \& Durbin 2010). DNA exome variant calling was performed on matched blood and tumor as well as PDX and cell lines using GATK and MuTect with default settings (McKenna et al. 2010, Cibulskis et al. 2013). Variant calls were annotated using ANNOVAR (Wang et al. 2010) and filtered with a custom R script. Mutations were considered deleterious if predicted damaging in at least three different in silico programs, including SIFT, Polyphen 2, MutationTaster and MutationAssessor (Kumar et al. 2009, Adzhubei et al. 2010, Reva et al. 2011, Schwarz et al. 2014).

\section{Plasmids, transfection and transduction}

The plasmid constructs used for transient transfection and transduction were pXOON-eGFP (Addgene, Cambridge, MA, USA) and pLenti-C-mGFP (OriGene, Rockville, MD, USA), respectively. ACC cells were plated on cover slips in 24-well plate for $24 \mathrm{~h}$ prior to transient transfection and transduction. For transfection, we used Lipofectamine 3000 system (ThermoFisher Scientific) per manufacture's protocol. Transient transduction using pLenti-C-mGFP was performed according to the standard protocol, and cells were fixed $48 \%$ after transduction. Stable cell lines were generated according to the standard protocol with plasmid selection. Cells were grown on coverslips for $48 \mathrm{~h}$ and fixed using ProLong Gold Antifade Mountant with DAPI (ThermoFisher Scientific). Slides were imaged using Nikon Eclipse E600 microscope (Nikon) equipped with a CoolSnap fx camera (Photometrics, Tucson, AZ, USA) and using ImagePro software (Media Cybernetics, Rockville, MD, USA). Cells that were positive for GFP were directly counted and normalized against the number of cells that were positive for DAPI in any given field. Five such fields were counted for each slide per experiment and average of three experimental replicates was used to calculate the transient transfection and transduction efficiency.

\section{Proliferation assay}

Proliferation assays were performed using the live imaging proliferation assay Incucyte ZOOM imaging system from Essen Biosciences (Ann Arbor, MI, USA). Cells were plated at a concentration of 5000 cells/well in a 96-well plate. Scans were conducted following the manufacturer's protocol under $4 \times$ magnification and images were quantified using nuclear counts. Cell counts at days 1 through 10 were measured. Doubling time was calculated using the formula $(T 2-T 1) /\left(3.32^{*}(\log n 2-\log n 1)\right)$, where $T$ stands for time and $n$ stands for the number of cells.

\section{Results}

\section{Clinical presentation}

\section{CU-ACC1}

The CU-ACC1 models were derived from a patient who initially presented elsewhere at age 66 years with hypertension, hypokalemia and a $4.8 \mathrm{~cm}$ left adrenal mass on CT scan. Hormonal evaluation revealed primary hyperaldosteronism with elevated aldosterone and undetectable renin levels, and with no clinical evidence of cortisol excess. A laparoscopic resection of a presumed benign aldosteronoma was performed. Two years later, she represented with worsening hypertension, hypokalemia and abdominal pain and on imaging was found to have evidence of ACC metastasis. Hormonal evaluation demonstrated no evidence of concomitant hyperaldosteronism. After transferring her care to our institution, she underwent resection of the left perinephric recurrence. The metastatic tumor was harvested for derivation of the CU-ACC1 cell line and PDX model. The patient received mitotane therapy, radiation to the tumor 
bed, chemotherapy with etoposide, doxorubicin and cisplatin and stabilized. Five years after initial diagnosis, she progressed rapidly. She was given two courses of immunotherapy without a response and died.

\section{CU-ACC2}

CU-ACC2 models were developed from a 26-year-old patient with Lynch syndrome. The patient had prior clinical genetic testing, which showed a germline deletion of exons 1-6 in MSH2. She presented to an outside institution with abdominal pain, no evidence of hormonal excess and was noted to have $>4 \mathrm{~cm}$ left adrenal mass, which ruptured when the surgeon attempted to resect it via laparoscopy. After transfer to our institution, radiation therapy was given to the left adrenal bed and subsequently the patient was started on mitotane. Recurrences developed in the liver, adrenal bed and lung over the next five years. Multiple surgeries, stereotactic body radiation therapy (SBRT) to lung metastases and embolic therapy to liver lesions were performed. The CU-ACC2 cell line and animal models were developed from a liver metastasis. The patient is now six years from her initial diagnosis and currently is undergoing treatment with immunotherapy and mitotane.

\section{Generation of ACC cell lines and PDX models}

Recent reports suggested that the use of feeder cells in the presence of a ROCK inhibitor is useful in immortalization of human tumors with an $88 \%$ success rate (Liu et al. 2012); therefore, we used this methodology for cell line development. Tumor samples were placed both directly onto Petri dish and onto feeder cells as described in methods. Neither CU-ACC1 nor CU-ACC2 cells grew initially in primary culture. Instead, both ACC cell lines were derived after passage of the human tumor samples in mice for 3-5 months (Fig. 1A and B). CU-ACC1 cells grew equally well directly on Petri dish or feeder cells (Fig. 1C). CU-ACC2 grew only on feeder cells (Fig. 1E). The CU-ACC2 cell lines were passaged 2-3 times on feeder cells and then transitioned to Petri dish alone. Both CU-ACC1 and CU-ACC2 have been passaged for 15 months with consistent appearance (Fig. 1C and E). After implanting the human tumors into the flank of nude mice, the time to harvest for the PDXs was initially 3 and 5 months for CU-ACC1 and CU-ACC2, respectively. The take rates for first-generation PDX models were 100\% (5/5 mice) for CU-ACC1 and 80\% (4/5 mice) for CU-ACC2. The time interval for passage has decreased from 90 days
(F1-F2) (take rate 100\% 3/3 mice) to 42 days (F10-F11) (take rate $60 \% 3 / 5$ mice) for CU-ACC1 and from 81 days (F1-F2) (take rate $80 \% 4 / 5$ mice) for CU-ACC2 to 63 days (F3-F4) (take rate $60 \% 3 / 5$ mice).

\section{STR profiling confirms match between new models} and human tissues

To ensure the cell lines and PDX models matched the human donor sample, STR profiling was performed. STR profiles were authenticated against ATCC, COG cell, DSMZ and NCBI online databases and verified to be unique. Complete STR profiling of the new models is outlined in Table 1. To insure species identification of the cell lines, Fig. 1D and E (upper panel) demonstrates that CU-ACC1 and CU-ACC2 lines expressed human, but not mouse markers. In addition, Fig. 1D and F (lower panel) demonstrates that current passages of CU-ACC1 and CU-ACC2 are not contaminated by murine 3T3 GFP-labeled feeder cells. CU-ACC1 cells and PDX were a 94\% match with CU-ACC1 human blood, and CU-ACC2 cells were a match at $94 \%$ and PDX at $96 \%$ with CU-ACC2 human tumor tissue (Table 2). These data confirm the correspondence between preclinical models and the respective human tissue.

\section{Immunohistochemistry and immunocytochemistry show structural similarity between PDX and human tumors}

To confirm the adrenal origin of the PDX tumors, immunohistochemistry (IHC) was performed. H\&E staining showed a similar architecture between matching pairs of PDX and human tissue, although CU-ACC1 and CU-ACC2 were quite different from each other (Figs 2A and $3 \mathrm{~A}$ ). Inhibin alpha and SF1 were retained in both human tumors and their respective PDX models. Melan-A was partially retained in CU-ACC1, but lost in CU-ACC2 PDX. Ki-67 staining was high in all the ACC models (Figs $2 \mathrm{~A}$ and $3 \mathrm{~A}$ ). $\beta$-catenin was cytoplasmic in both CU-ACC1 and CU-ACC2 human tumor and PDX, with higher expression in CU-ACC1 models. p53 expression in CU-ACC2 tissue was dramatically higher compared to CU-ACC1. As expected, MSH2 staining was lost in both CU-ACC2 tumor and PDX consistent with the clinical diagnosis of Lynch syndrome, but was retained in CU-ACC1 samples (Figs 2B and 3B).

Similar to IHC, immunocytochemistry of the ACC cell lines demonstrated strong SF1 positivity in CU-ACC1 cells, while SF1 expression in CU-ACC2 cell was much 

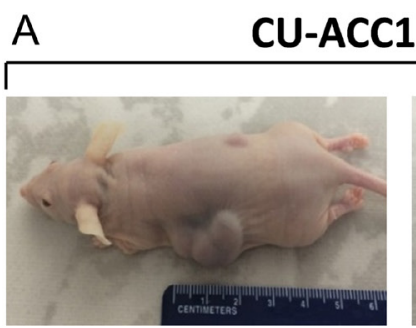

C
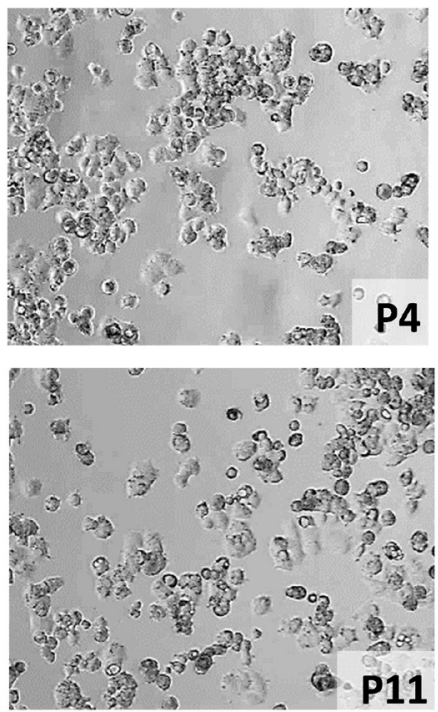
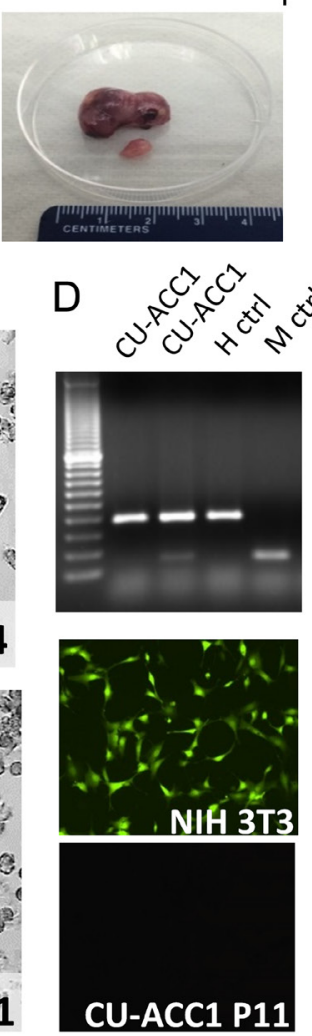

B

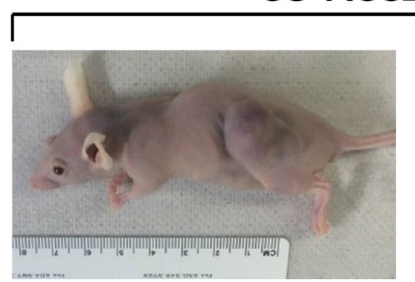

\section{$E$}

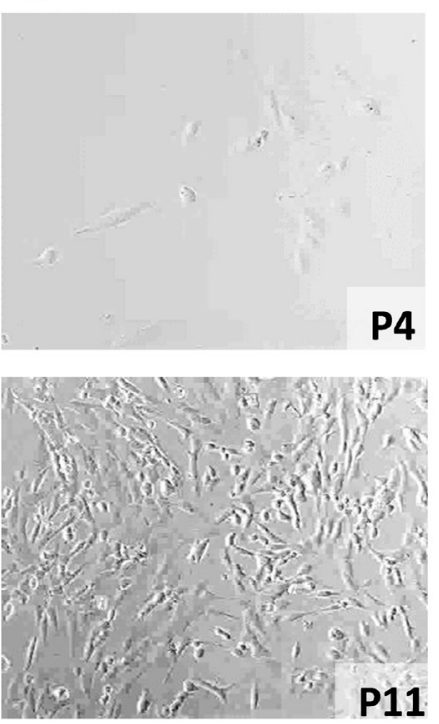

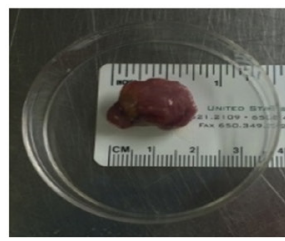

$\mathrm{F}$
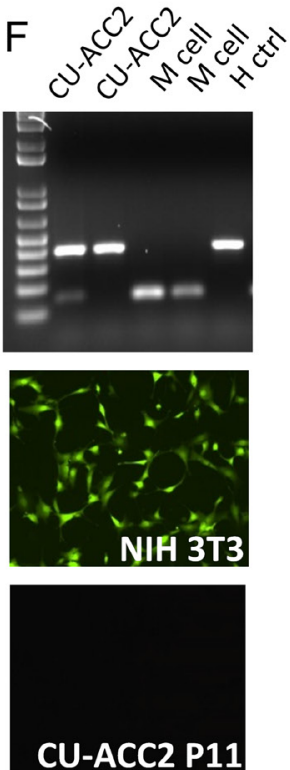

Figure 1

Generation of ACC preclinical models. (A) CU-ACC1- and (B) CU-ACC2-nude mouse PDXs at the time of harvesting of the first passage. (C) The appearance of CU-ACC1 cell line at passage 4 (10x) (upper panel) and passage 11 (10x) (lower panel). (D) Species identification by genomic DNA approach confirming human origin (upper panel), and no 3T3-GFP-tagged contamination is present in CU-ACC1 cells (lower panel). (E) The appearance of CU-ACC2 cell line at passage 4 (10x) (upper panel) and passage 11 (10x) (lower panel). (F) Species identification by genomic DNA approach confirming human origin (upper panel), and no 3T3-GFP-tagged contamination is present in CU-ACC2 cells (lower panel).

less. As expected, Ki-67 expression was high in both new cell lines (Figs 2C and 3C).

\section{Exome profiling and RNA sequencing of new ACC cell and animal models}

Analysis of the exome sequencing data for genes frequently mutated in ACC (Assie et al. 2014), identified a CTNNB1 mutation in CU-ACC1 and TP53 mutation in CU-ACC2, with the frequency of mutated alleles being higher in the cell lines and PDXs compared to human tumor samples (Fig. 4A), suggesting enrichment of the mutated clones, and the frequency of the mutated CTNNB1 allele in CU-ACC1 most likely suggests some early passage polyclonality of the novel cell line. The CTNNB1 mutation detected in CU-ACC1 was predicted as damaging using at least three in silico callers and has been previously reported in ACC (Zheng et al. 2016, Creemers et al. 2017). The TP53 mutation in the CU-ACC2 tissue was predicted as damaging using three in silico callers and has also been described in ACC (Barzon et al. 2001). As expected, based on clinical genetic testing, exons 1-6 of $\mathrm{MSH} 2$ were deleted in the CU-ACC2 models (Fig. 4B). A heterozygous deletion of exons 1-6 in MSH2 was seen in $50 \%$ of the reads in the human blood. By comparison, there was a complete loss of heterozygosity in the human tumor, PDX and cell line confirming the validity of these new models for the Lynch syndrome mutation. The mutation status of CU-ACC1 and CU-ACC2 replicates that of known subsets of human ACC tumors reflecting the relevance of these new models for future investigation.

Using RNAseq profiling, a principle component analysis (PCA) plot was constructed to examine whether the expression profiles differed between the standard H295R cells and the newly developed ACC models (Fig. 5, http://erc.endocrinology-journals.org https://doi.org/10.1530/ERC-17-0447 (c) 2018 Society for Endocrinology Published by Bioscientifica Ltd. Printed in Great Britain 
upper left panel). The PCA plot demonstrated separation of gene expression between H295R, normal adrenal samples (obtained from GTeX project), CU-ACC1 cells and PDX and CU-ACC2 cells and PDX. Each new cell line and corresponding PDX was clustered together.

The expression of adrenal markers SF1 and STAR, CYP11B1 and CYP11B2, AGTR1, MC2R and MRAP, as well as some of the known dysregulated genes representing biomarkers in ACC including IGF2, BUB1B, PINK and CTNNB1, were profiled from RNAseq data (Fig. 5). These data confirmed that the new models have high expression of adrenal markers and variable expression of specific biomarkers reflecting the different origin and molecular landscape of the human ACC tumors.

\section{LC-MS/MS measurements of steroid hormones}

To further characterize the two new ACC tumor cell lines, a steroid secretome profile was measured using LC-MS/MS compared to H295R cells (Fig. 6). CU-ACC1, which was taken from a patient who initially presented with elevated aldosterone levels (but not at the time of metastasis from which the models were derived), demonstrated basal cortisol and corticosterone secretion, and no evidence of aldosterone or DHEA secretion. The baseline cortisol levels in CU-ACC1 were about 4-fold higher compared to H295R cells under similar culture conditions. No further increase in hormone secretion was observed when the cells were stimulated with either adrenocorticotropin (ACTH) or angiotensin. CU-ACC2 cells secreted only minute amounts of cortisol and were unresponsive to hormone stimulation. In response to forskolin, H295R cells showed a trend to an increase in 11-deoxycortsiol secretion $(P=0.09)$, while CU-ACC1 cells demonstrated a robust increase (1.9-fold) in cortisol secretion $(P=0.02)$ (Fig. 6$)$.

Table 2 Short Tandem Repeats (STR) match human tissues to new models.

\begin{tabular}{|c|c|c|c|c|c|}
\hline $\begin{array}{l}\text { Sample } \\
\text { name }\end{array}$ & $\begin{array}{l}\text { Ref } \\
\text { name }\end{array}$ & $\begin{array}{l}\text { Shared } \\
\text { alleles }\end{array}$ & $\begin{array}{l}\text { Sample } \\
\text { alleles }\end{array}$ & $\begin{array}{c}\text { Ref } \\
\text { alleles }\end{array}$ & $\%$ match \\
\hline \multicolumn{6}{|c|}{ CU-ACC1 } \\
\hline PDX & Blood & 25 & 28 & 28 & 94 \\
\hline Cells & Blood & 25 & 28 & 28 & 94 \\
\hline Cells & PDX & 28 & 28 & 28 & 100 \\
\hline \multicolumn{6}{|c|}{ CU-ACC2 } \\
\hline PDX & Tumor & 22 & 25 & 23 & 96 \\
\hline Cells & Tumor & 22 & 24 & 23 & 94 \\
\hline Cells & PDX & 24 & 25 & 24 & 98 \\
\hline
\end{tabular}




\section{CU-ACC1}

A
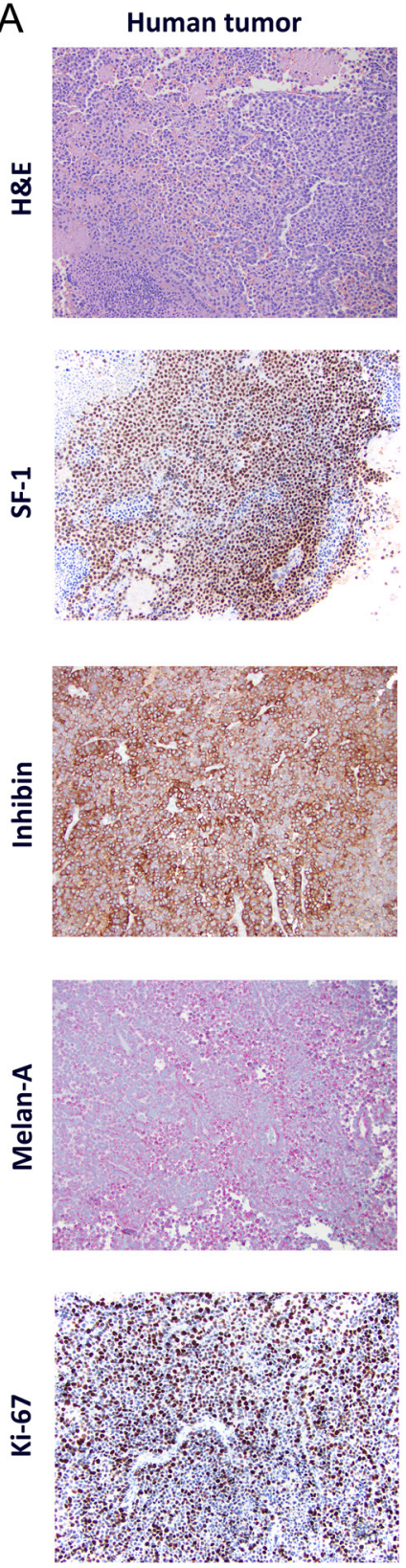

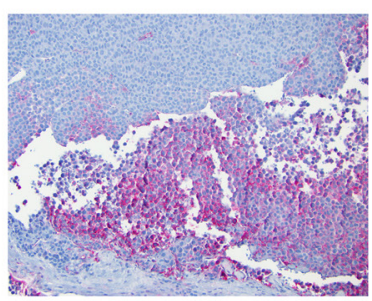

PDX
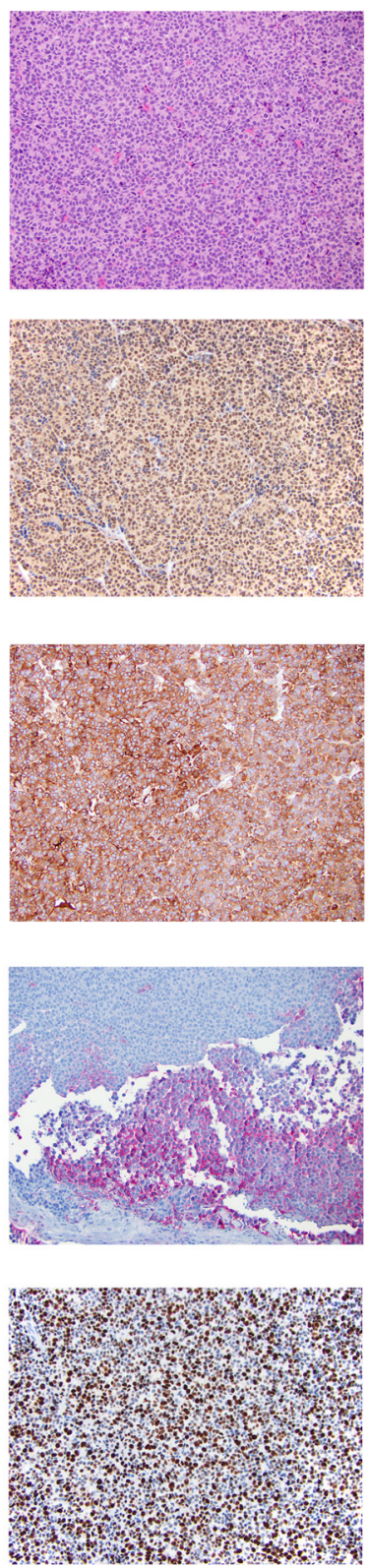

B
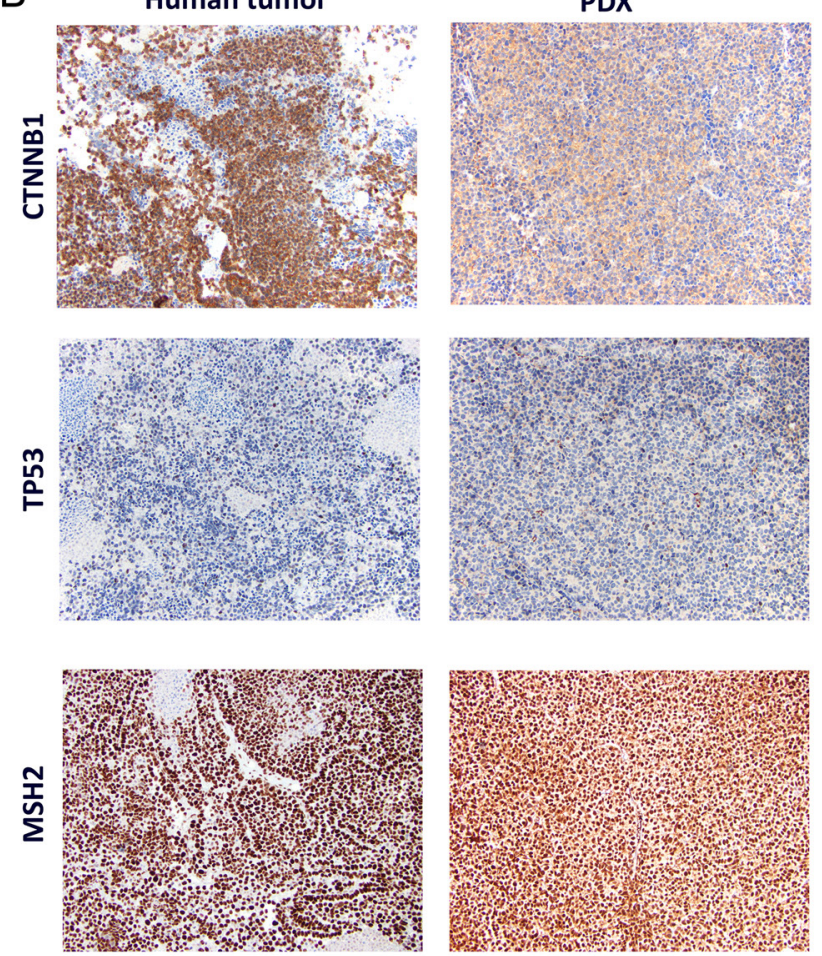

C

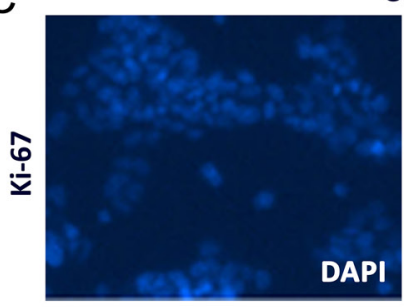

Cells

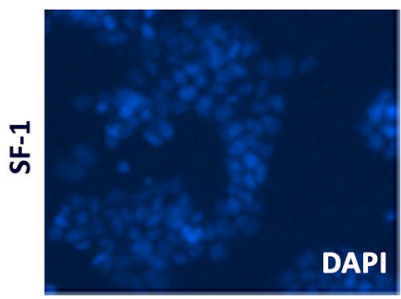

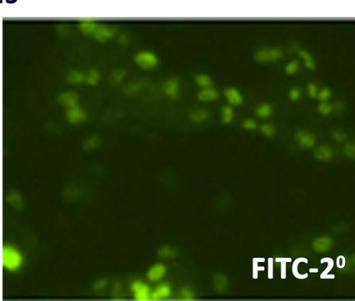

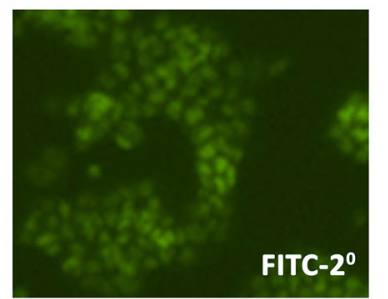

Figure 2

Immunohistochemistry of human CU-ACC1 tumor and CU-ACC1 PDX. (A and B) The left columns show CU-ACC1 human tumor sample and the right two columns are from CU-ACC1 PDX. (A) The immunochemistry stains include H\&E, SF1, $\alpha$-inhibin, Melan-A, Ki-67 and (B) $\beta$-catenin , p53 and MSH2 (C). Immunocytochemistry for Ki67 and SF1 (right columns) for CU-ACC1 cells (DAPI - left column).

\section{Rates of proliferation and doubling times}

We next determined the growth rates of the new ACC cell lines compared to H295R cells (Fig. 7A). Whereas H295R cells had a doubling time of $25 \mathrm{~h}$, CU-ACC1 (passage 10) cells had a doubling time of $35 \mathrm{~h}$ and CU-ACC2 (passage 10) of $29 \mathrm{~h}$ (Fig. 7B). To assess the transfectability of the new cell models for experimental manipulation, each cell line was exposed to transient transfection with a GFP-tagged expression vector using lipid reagents, as well as transduced using GFP-lentiviral vector. Transient transfection rates at $48 \mathrm{~h}$ were $8 \%$ and $16 \%$, and transduction rates were $24 \%$ and $28 \%$ for CU-ACC1 and CU-ACC2, respectively. Importantly, transduction followed by stable plasmid selection was comparable in our new models to that of H295R (Supplementary Fig. 1, 


\section{CU-ACC2}

A
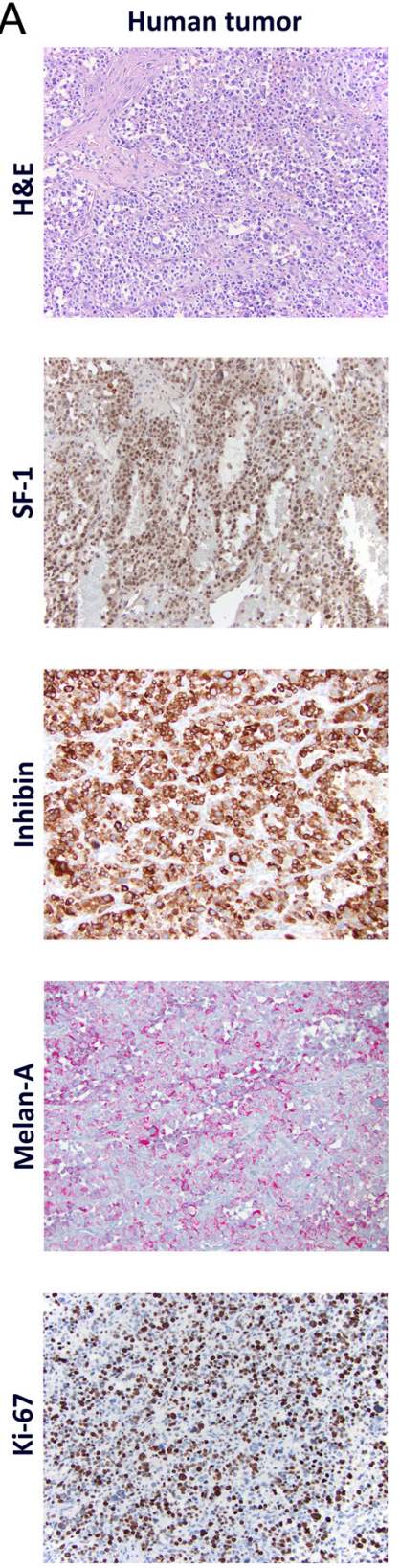

PDX
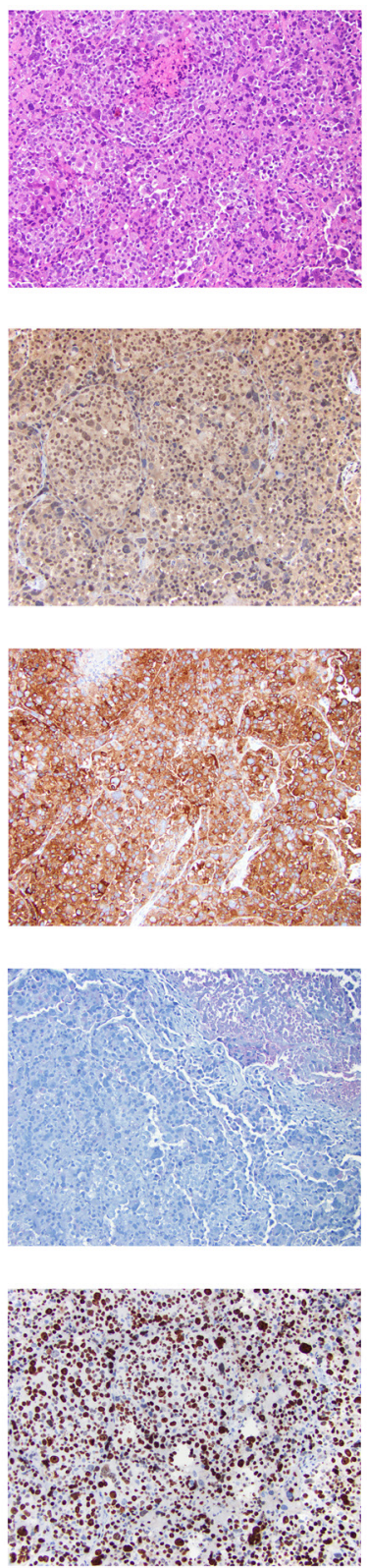

B
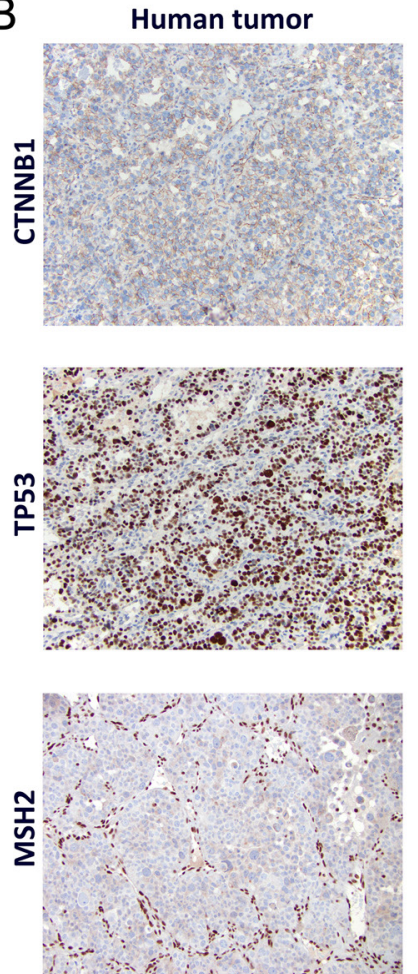

C

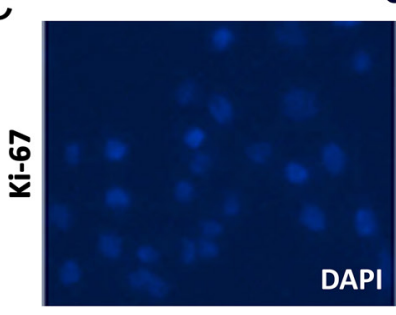

Cells

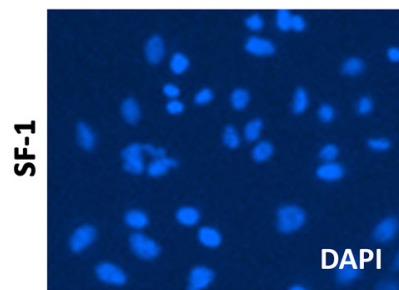

PDX
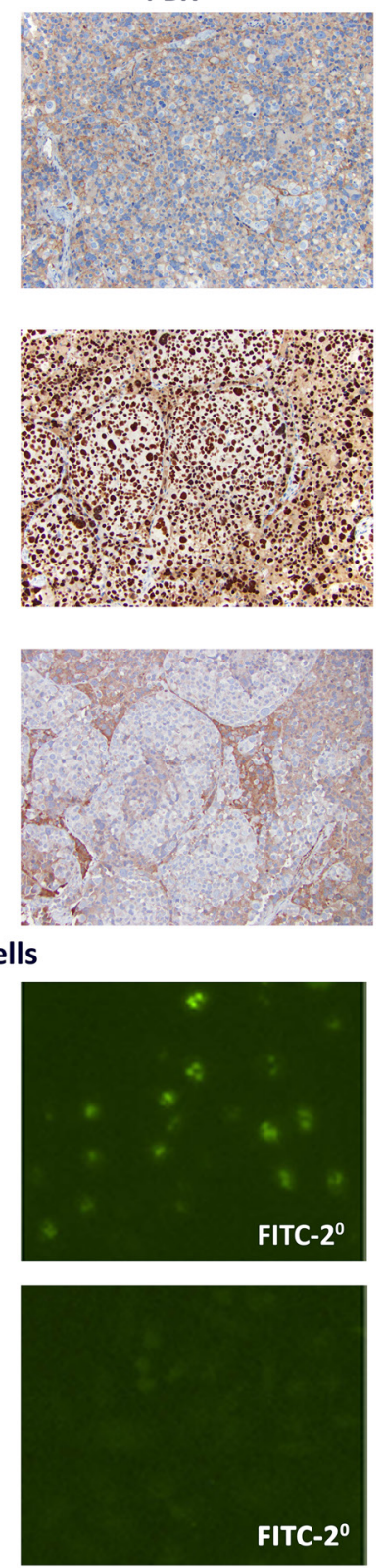

\section{Figure 3}

Immunohistochemistry of human CU-ACC2 tumor and CU-ACC2 PDX. (A and B) The left columns show CU-ACC2 human tumor sample and the right two columns are from CU-ACC2 PDX. (A) The immunochemistry stains include H\&E, SF1, $\alpha$-inhibin, Melan-A, Ki-67 and (B) $\beta$-catenin , p53 and MSH2 (C) Immunocytochemistry for Ki67 and SF1 (right columns) for CU-ACC2 cells (DAPI left column).

see section on supplementary data given at the end of this article). These data confirm the utility of these new ACC cell lines for in vitro studies.

\section{Discussion}

The scarcity of preclinical research models has contributed to the slow progress toward developing targeted therapies for the patients with ACC. The rarity of the disease as well as hormonal activity of tumor cells have been reported to be the major barriers toward establishing new adrenocortical cell lines and animal models (Wang \& Rainey 2012, Hantel et al. 2016). Taking advantage of new in vitro techniques utilizing ROCK inhibitor and feeders cells, and experience in development of PDX models, we have been successful in 


\begin{tabular}{|l|c|c|c|c|c|}
\hline \multirow{2}{*}{ A } & \multirow{2}{*}{ Gene } & \multirow{2}{*}{ Mutation } & \multicolumn{3}{|c|}{ Allele frequency } \\
\cline { 4 - 6 } & & & Tumor & PDX & Cells \\
\hline CU-ACC1 & CTNNB1 & exon3:c.G100A:p.G34R & $14 \%$ & $25 \%$ & $26 \%$ \\
\hline CU-ACC2 & TP53 & exon7:c.G337A:p.G245S & $98 \%$ & $99 \%$ & $100 \%$ \\
\hline
\end{tabular}

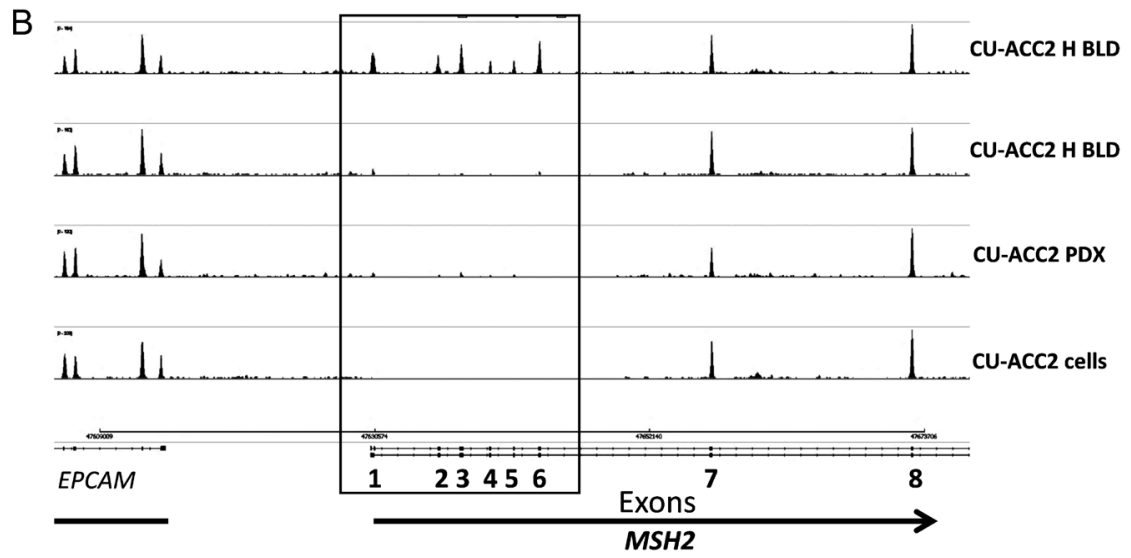

\section{Figure 4}

Whole exome sequencing of preclinical ACC models. (A) Exome sequencing analysis of the human tumor sample and models revealed evidence of a CTNNB1 mutation in CU-ACC1 tissues and a TP53 mutation in CU-ACC2 tissues. Mutated gene allele frequencies were higher in the models compared to primary human tumors showing enrichment for the mutated clones. (B) Sashimi plot of the CU-ACC2 human blood (H blood) confirms the heterozygous germline loss of MSH2 exons 1-6, with a complete loss of heterozygosity in the human tumor (H tumor), PDX and cell line. developing two new ACC tumor cell lines and matched PDX models that will allow investigators to explore ACC pathogenesis, test biomarkers of disease and evaluate new treatment targets. We also have performed the first extensive genomic, genetic, targeted protein and secretome profiling of these new preclinical models. With the diversity of clinical phenotypes and molecular genotypes in tumors translating to variable prognosis for patients with adrenocortical carcinoma, multiple models are needed to derive patient-specific targeted therapy.

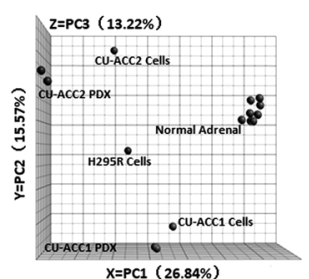

SF1
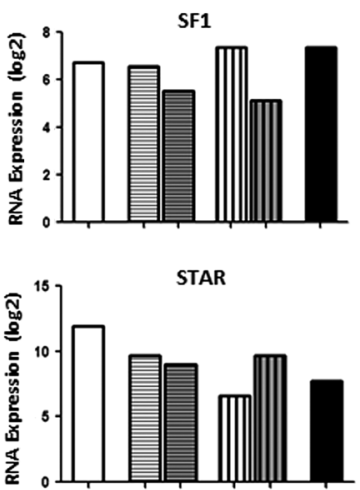

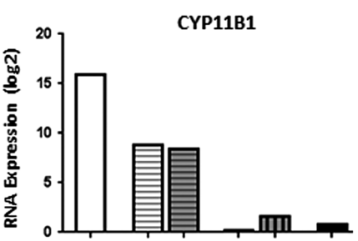

MC2R

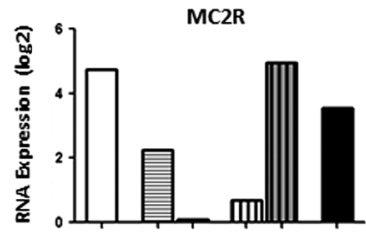

IGF2

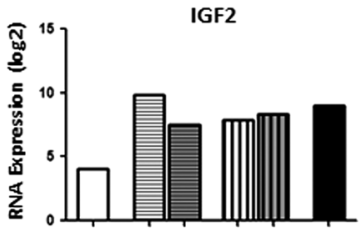

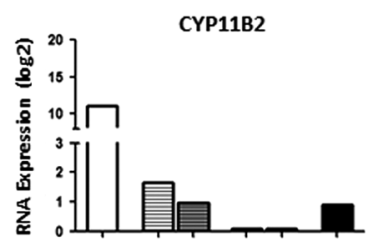
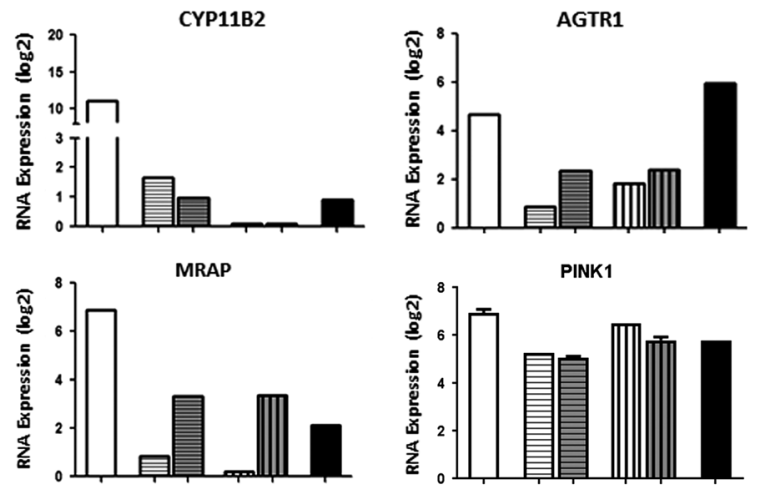

II

III) CU-ACC2 PDX

H295R
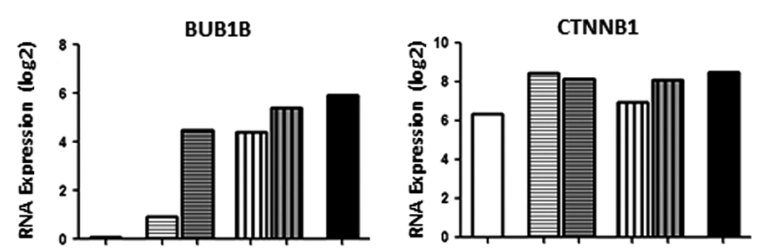

Figure 5

RNA sequencing data analysis of preclinical ACC models. Left upper panel: PCA of RNA sequencing profiles of normal adrenal compared with ACC cell lines and PDX models. Right upper panel and lower panels: Samples of normal adrenal $(n=6)$, H295R cells $(n=1)$ and newly developed models (CU-ACC1 and CU-ACC2 cells $n=1$ each, PDX $n=2$ each) were analyzed for transcript expression by RNA sequencing. Select transcript expression log2 levels are shown for adrenal specific markers (SF1, STAR, CYP11B1, CYP11B2, AGTR1, MCR2 and MRAP) as well as some of the known dysregulated genes in ACC (IGF2, BUB1B, PINK, CTNNB1). 

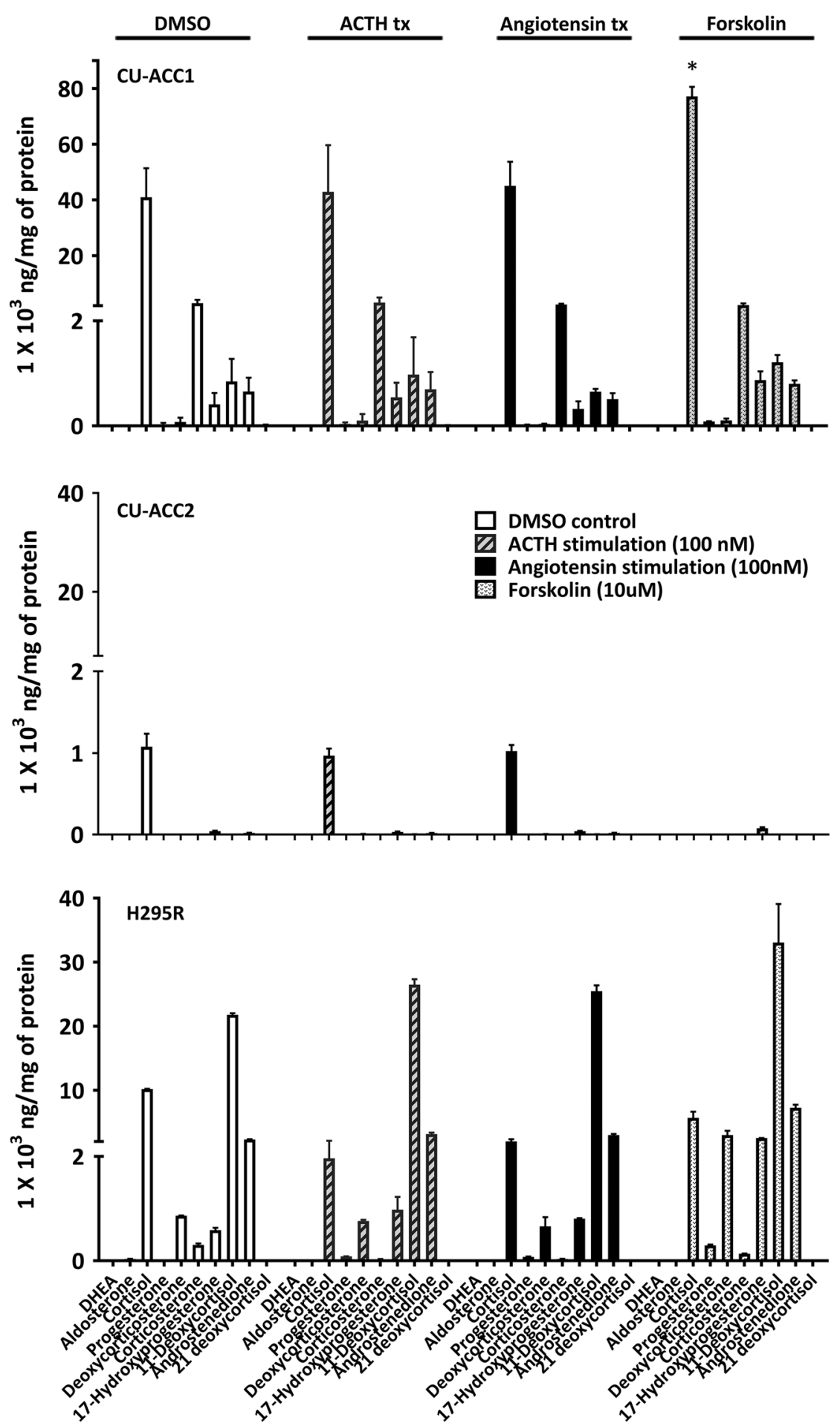

Figure 6

LC-MS/MS analyzed steroid secretion profiles of CU-ACC1, CU-ACC2 and H295R ACC cell lines. Adrenal steroid secretome was analyzed at baseline (DMSO), and after ACTH $100 \mathrm{nM}$, angiotensin $100 \mathrm{nM}$ and forskolin $10 \mu \mathrm{M}$ treatment for $24 \mathrm{~h}$.

At the genetic level, these new ACC cell lines and PDX models represent examples of known molecular defects detected in human ACC with mutations in CTNNB1, TP53 and MSH2. H295R cells have a known activating mutation in CTNNB1 (Gaujoux et al. 2013), and whole exome sequencing identified a mutation in CTNNB1 (p.G34R) in the CU-ACC1 models that has been previously reported in ACC tumor samples (Zheng et al. 2016, Creemers et al. 2017). The precise functional significance of this mutation is not yet been reported, but the G34R location within the 

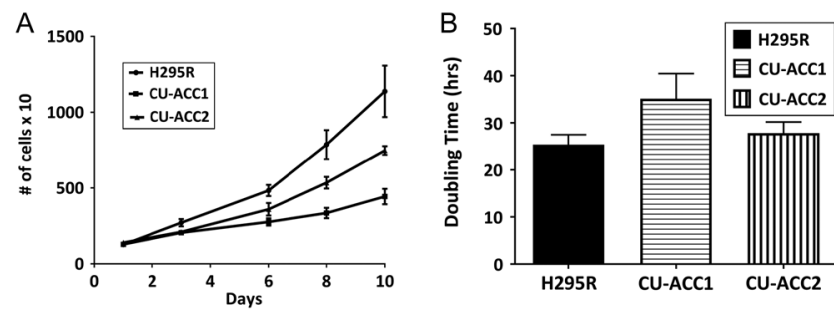

Figure 7

Newly developed cell lines proliferate. (A) Compared to H295R, both CU-ACC1 and CU-ACC2 cells show lower rates of proliferation. (B) Doubling times for the ACC cell lines were determined. H295R cells have a doubling time of $25 \mathrm{~h}, \mathrm{CU}-\mathrm{ACC} 135 \mathrm{~h}$ and CU-ACC2 $29 \mathrm{~h}$.

ubiquitination recognition motif of the protein predicts a gain-of-function mutation (Terris et al. 1999, Ikeda et al. 2000, Al-Fageeh et al. 2004). In addition, the pancancer MSK-IMPACT study has identified this mutation in multiple malignancies including lung, liver, uterine and bladder cancer (Zehir et al. 2017). Consistent with these data, a recent study exploring mutation hotspots in CTNNB1 identified G34R as a recurrent mutation across various cancer types (Chang et al. 2016).

The TP53 mutation (G245S) identified in the CU-ACC2 models has also been previously reported in adrenocortical carcinoma samples (Barzon et al. 2001). Although the functional significance has not been yet elucidated, crystallographic studies have identified G245S as a cancer hotspot mutation in TP53 in abrogating DNA binding, where it induces conformational change in structure (Joerger et al. 2006). MSH2 mutations have been well described as critical components of the Lynch syndrome phenotype, which has been reported in subpopulation of patients with adrenocortical carcinoma (Else et al. 2014). Interestingly, the allele frequency for both the CTNNB1 and TP53 mutation was higher in the preclinical models when compared to the human tumor, suggesting that models, and especially cell lines, are enriched for the mutated allele.

RNAseq analysis was performed to obtain a global gene expression profile of our newly created preclinical models to confirm that the models clustered with the human tumor of origin. Our goal was to establish the molecular signature of each model for comparison across interventions in this heterogeneous disease. We evaluated the expression of several transcripts that have been previously shown to be upregulated in ACC or normal adrenal. SF1 is expressed in adrenal, gonadal (Zhao et al. 2008) and pituitary gonadotrope cells (Zhao et al. 2001) and is often used as a marker of adrenocortical origin (Sbiera et al. 2010). SF1 overexpression has been reported in SJ-ACC3 and the recently derived MUC-1 cell line (Hantel et al. 2016). SF1 mRNA expression levels in our newly developed models was comparable to that of H295R ACC cells confirming their adrenocortical origin. In addition, other adrenal markers such as CYP11B1, CYP11B2, AGTR1, MCR2 and $M R A P$ demonstrated differential expression compared to normal adrenal and $\mathrm{H} 295 \mathrm{R}$ cells, reflecting the heterogeneity of adrenal tumors. IGF-2, BUB1b, PINK and $C T N N B 1$ are several adrenal markers previously characterized in ACC (Else 2012), and our models align with expression of H295R as well as expression profiles of ACC reported in TCGA and ENSAT databases (Assie et al. 2014, Zheng et al. 2016). It is important to point out that the RNAseq of normal adrenal expression was extracted from GTex project and a batch effect is a potential limitation of the study when comparing expression levels of normal adrenal to our preclinical models.

To corroborate observed changes in adrenal markers in the RNAseq analysis, we examined the protein level expression of adrenocortical markers commonly used in clinical pathology to confirm a diagnosis of ACC using immunohistochemistry. The PDX tumors were histologically similar to their matching human tissue of origin on H\&E stain. Whereas Melan-A had some variability in expression in the PDX tumors, a-Inhibin and SF1 were strongly positive in all samples. Interestingly, the RNAseq showed equivalent mRNA expression for the new ACC cell lines compared to H295R; yet, immunocytochemistry demonstrated strong staining for SF1 in CU-ACC1 comparable to that reported for H295R cells, MUC-1 cells/PDX and SJ-ACC3 PDX, whereas the staining in CU-ACC2 was lower, suggesting potential dedifferentiation of the cell line in culture. Both CU-ACC1 and CU-ACC2 human samples and PDX were positive for cytoplasmic $\beta$-catenin similarly to the MUC1 PDX, with higher expression in CU-ACC1. p53 expression was higher in CU-ACC2 compared to CU-ACC1 tissues. As expected, Ki-67 staining was high in all the tissues as well as cell lines. MSH2 staining was strongly positive in CU-ACC1 tissues and absent in CU-ACC2 with known mutation in the $\mathrm{MSH} 2$ gene.

In our experience and consistent with the literature, approximately $40-60 \%$ of patients with ACC present clinically with evidence of excess hormone secretion (Else 2012). Our CU-ACC1 patient initially presented with hyperaldosteronism, which is relatively rare in ACC (Seccia et al. 2005, Abiven et al. 2006). Subsequently, when the patient presented with metastatic disease, the 
tumor was de-differentiated with no evidence of excess aldosterone. The CU-ACC2 patient did not present with any excess hormonal activity. To evaluate the secretome of our newly created cell lines, we performed LS/MS-MS analysis to profile adrenal hormones and compared these profiles to that of H295R cells. Whereas H295R cells secreted moderate levels of 11-deoxycortisol in basal conditions, as previously reported (Nanba et al. 2016), CU-ACC1 cells secreted cortisol which is in line with higher expression of CYP11B1 mRNA in CU-ACC1 compared to H295R. No aldosterone secretion was detected in CU-ACC1. Whereas treatment with forskolin mildly induced 11-deoxycortsiol levels in H295R cells, it significantly increased the secretion of cortisol in CU-ACC1, 1.9-fold. In contrast, CU-ACC2 cells, did not secrete any hormones at basal condition or with addition of ACTH, angiotensin or forskolin.

The early passages of our newly reported cell line models, as compared to well established ACC cell line in the field, H295R, proliferate more slowly and had longer doubling time, which is not unexpected considering that they were generated relatively recently. Nevertheless, we have been able to successfully transduce and transfect them, and they are equivalent to H295R cells upon stable selection. Functional studies of several candidate genes involved in ACC tumorigenesis are underway in our laboratory. Based on these exciting results, we are in the process of developing additional models from primary and metastatic ACC lesions. We foresee that these models will represent specific molecular signatures of subgroups of ACC tumors where drug screening can be performed in vitro followed by testing in vivo in the relevant PDX model to contribute to a personalized approach for treating ACC patients.

\section{Supplementary data}

This is linked to the online version of the paper at https://doi.org/10.1530/ ERC-17-0447.

\section{Declaration of interest}

The authors declare that there is no conflict of interest that could be perceived as prejudicing the impartiality of the research reported.

\section{Funding}

This work was supported by Veterans Affairs Merit Review Award 001 and the Adrenal Tumor Program Fund (to M E W), NIH K12CA086913-12 (to K K V), Cancer League of Colorado Award (to K K V and S L), Doris Duke CU-FSRC (to K K V) University of Colorado Cancer Center Support Grant P30-CA046934 and the Cancer Center Genomics Core.

\section{Acknowledgments}

The authors thank Dr Robert Murphy and Charis Uhlson for performance of the LC-MS/MS measurements of steroid hormones in the Mass Spectrometry Lipidomics Core Facility at the University of Colorado Anschutz Medical Campus. The authors also thank Dr Wilbur A. Franklin for the help with extraction of DNA from CU-ACC1 human tumor block. The authors thank Dr Bifeng Gao and Katrina Diener for help with NextGeneration Sequencing of newly developed models in the Genomics and Microarray Core Facility. The authors thank Dr Shyh-Haw Tsay and Andrea Osypuk for their aid in procurement of the fresh human tissue for preclinical model development. The authors also thank Dr Constanze Hantel for help with optimization of SF1 immunohistochemistry protocol. The results in this manuscript contain data generated by GTEx Portal https://www.gtexportal.org/home/.

\section{References}

Abiven G, Coste J, Groussin L, Anract P, Tissier F, Legmann P, Dousset B, Bertagna X \& Bertherat J 2006 Clinical and biological features in the prognosis of adrenocortical cancer: poor outcome of cortisolsecreting tumors in a series of 202 consecutive patients. Journal of Clinical Endocrinology and Metabolism 91 2650-2655. (https://doi.org/10.1210/jc.2005-2730)

Adam P, Hahner S, Hartmann M, Heinrich B, Quinkler M, Willenberg HS, Saeger W, Sbiera S, Schmull S, Voelker HU, et al. 2010 Epidermal growth factor receptor in adrenocortical tumors: analysis of gene sequence, protein expression and correlation with clinical outcome. Modern Pathology 23 1596-1604. (https://doi.org/10.1038/ modpathol.2010.153)

Adzhubei IA, Schmidt S, Peshkin L, Ramensky VE, Gerasimova A, Bork P, Kondrashov AS \& Sunyaev SR 2010 A method and server for predicting damaging missense mutations. Nature Methods 7 248-249. (https://doi.org/10.1038/nmeth0410-248)

Al-Fageeh M, Li Q, Dashwood WM, Myzak MC \& Dashwood RH 2004 Phosphorylation and ubiquitination of oncogenic mutants of beta-catenin containing substitutions at Asp32. Oncogene $\mathbf{2 3}$ 4839-4846. (https://doi.org/10.1038/sj.onc.1207634)

Allolio B \& Fassnacht M 2006 Clinical review: adrenocortical carcinoma: clinical update. Journal of Clinical Endocrinology and Metabolism 91 2027-2037. (https://doi.org/10.1210/jc.2005-2639)

Assie G, Letouze E, Fassnacht M, Jouinot A, Luscap W, Barreau O, Omeiri H, Rodriguez S, Perlemoine K, Rene-Corail F, et al. 2014 Integrated genomic characterization of adrenocortical carcinoma. Nature Genetics 46 607-612. (https://doi.org/10.1038/ng.2953)

Bagby S, Messersmith WA, Pitts TM, Capasso A, Varella-Garcia M, Klauck PJ, Kim J, Tan AC, Eckhardt SG, Tentler JJ, et al. 2016 Development and maintenance of a preclinical patient derived tumor xenograft model for the investigation of novel anti-cancer therapies. Journal of Visualized Experiments 115 e54393. (https://doi.org/10.3791/54393)

Barzon L, Chilosi M, Fallo F, Martignoni G, Montagna L, Palu G \& Boscaro M 2001 Molecular analysis of CDKN1C and TP53 in sporadic adrenal tumors. European Journal of Endocrinology 145 207-212. (https://doi.org/10.1530/eje.0.1450207)

Berruti A, Sperone P, Ferrero A, Germano A, Ardito A, Priola AM, De Francia S, Volante M, Daffara F, Generali D, et al. 2012 Phase II study of weekly paclitaxel and sorafenib as second/third-line therapy in patients with adrenocortical carcinoma. European Journal of Endocrinology 166 451-458. (https://doi.org/10.1530/EJE-11-0918)

Berruti A, Grisanti S, Pulzer A, Claps M, Daffara F, Loli P, Mannelli M, Boscaro M, Arvat E, Tiberio G, et al. 2017 Long-term outcomes of adjuvant mitotane therapy in patients with radically resected adrenocortical carcinoma. Journal of Clinical Endocrinology and Metabolism 102 1358-1365. (https://doi.org/10.1210/jc.2016-2894) 
Bradford AP, Jones K, Kechris K, Chosich J, Montague M, Warren WC, May MC, Al-Safi Z, Kuokkanen S, Appt SE, et al. 2015 Joint MiRNA/ mRNA expression profiling reveals changes consistent with development of dysfunctional corpus luteum after weight gain. PLoS ONE 10 e0135163. (https://doi.org/10.1371/journal.pone.0135163)

Chang MT, Asthana S, Gao SP, Lee BH, Chapman JS, Kandoth C, Gao J, Socci ND, Solit DB, Olshen $\mathrm{AB}$, et al. 2016 Identifying recurrent mutations in cancer reveals widespread lineage diversity and mutational specificity. Nature Biotechnology 34 155-163. (https://doi.org/10.1038/nbt.3391)

Cibulskis K, Lawrence MS, Carter SL, Sivachenko A, Jaffe D, Sougnez C, Gabriel S, Meyerson M, Lander ES \& Getz G 2013 Sensitive detection of somatic point mutations in impure and heterogeneous cancer samples. Nature Biotechnology 31 213-219. (https://doi.org/10.1038/nbt.2514)

Cooper JK, Sykes G, King S, Cottrill K, Ivanova NV, Hanner R \& Ikonomi P 2007 Species identification in cell culture: a two-pronged molecular approach. In Vitro Cellular and Developmental Biology Animal 43 344-351. (https://doi.org/10.1007/s11626-007-9060-2)

Creemers SG, Korpershoek E, Atmodimedjo PN, Dinjens WNM, van Koetsveld PM, Feelders RA \& Hofland LJ 2017 Identification of mutations in cell-free circulating tumor DNA in adrenocortical carcinoma: a case series. Journal of Clinical Endocrinology and Metabolism 102 3611-3615. (https://doi.org/10.1210/jc.2017-00174)

Else T 2012 Association of adrenocortical carcinoma with familial cancer susceptibility syndromes. Molecular and Cellular Endocrinology $\mathbf{3 5 1}$ 66-70. (https://doi.org/10.1016/j.mce.2011.12.008)

Else T, Kim AC, Sabolch A, Raymond VM, Kandathil A, Caoili EM, Jolly S, Miller BS, Giordano TJ \& Hammer GD 2014 Adrenocortical carcinoma. Endocrine Reviews 35 282-326. (https://doi.org/10.1210/ er.2013-1029)

Fassnacht M, Terzolo M, Allolio B, Baudin E, Haak H, Berruti A, Welin S, Schade-Brittinger C, Lacroix A, Jarzab B, et al. 2012 Combination chemotherapy in advanced adrenocortical carcinoma. New England Journal of Medicine 366 2189-2197. (https://doi.org/10.1056/ NEJMoa1200966)

Fassnacht M, Berruti A, Baudin E, Demeure MJ, Gilbert J, Haak H, Kroiss M, Quinn DI, Hesseltine E, Ronchi CL, et al. 2015 Linsitinib (OSI-906) versus placebo for patients with locally advanced or metastatic adrenocortical carcinoma: a double-blind, randomised, phase 3 study. Lancet Oncology 16 426-435. (https://doi.org/10.1016/ S1470-2045(15)70081-1)

Gaujoux S, Hantel C, Launay P, Bonnet S, Perlemoine K, Lefevre L, Guillaud-Bataille M, Beuschlein F, Tissier F, Bertherat J, et al. 2013 Silencing mutated beta-catenin inhibits cell proliferation and stimulates apoptosis in the adrenocortical cancer cell line H295R. PLOS ONE 8 e55743. (https://doi.org/10.1371/journal.pone.0055743)

Gazdar AF, Oie HK, Shackleton CH, Chen TR, Triche TJ, Myers CE, Chrousos GP, Brennan MF, Stein CA \& La Rocca RV 1990 Establishment and characterization of a human adrenocortical carcinoma cell line that expresses multiple pathways of steroid biosynthesis. Cancer Research 50 5488-5496.

Gross DJ, Munter G, Bitan M, Siegal T, Gabizon A, Weitzen R, Merimsky O, Ackerstein A, Salmon A, Sella A, et al. 2006 The role of imatinib mesylate (Glivec) for treatment of patients with malignant endocrine tumors positive for c-kit or PDGF-R. Endocrine-Related Cancer 13 535-540. (https://doi.org/10.1677/erc.1.01124)

Grubbs EG, Callender GG, Xing Y, Perrier ND, Evans DB, Phan AT \& Lee JE 2010 Recurrence of adrenal cortical carcinoma following resection: surgery alone can achieve results equal to surgery plus mitotane. Annals of Surgical Oncology 17 263-270. (https://doi. org/10.1245/s10434-009-0716-x)

Haluska P, Worden F, Olmos D, Yin D, Schteingart D, Batzel GN, Paccagnella ML, de Bono JS, Gualberto A \& Hammer GD 2010 Safety, tolerability, and pharmacokinetics of the anti-IGF-1R monoclonal antibody figitumumab in patients with refractory adrenocortical carcinoma. Cancer Chemotherapy and Pharmacology 65 765-773. (https://doi.org/10.1007/s00280-009-1083-9)

Hantel C, Shapiro I, Poli G, Chiapponi C, Bidlingmaier M, Reincke M, Luconi M, Jung S \& Beuschlein F 2016 Targeting heterogeneity of adrenocortical carcinoma: evaluation and extension of preclinical tumor models to improve clinical translation. Oncotarget 7 79292-79304.

Hill M, Parizek A, Cibula D, Kancheva R, Jirasek JE, Jirkovska M, Velikova M, Kubatova J, Klimkova M, Paskova A, et al. 2010 Steroid metabolome in fetal and maternal body fluids in human late pregnancy. Journal of Steroid Biochemistry and Molecular Biology 122 114-132. (https://doi.org/10.1016/j.jsbmb.2010.05.007)

Ikeda T, Yoshinaga K, Semba S, Kondo E, Ohmori H \& Horii A 2000 Mutational analysis of the CTNNB1 (beta-catenin) gene in human endometrial cancer: frequent mutations at codon 34 that cause nuclear accumulation. Oncology Reports 7 323-326.

Jantti SE, Hartonen M, Hilvo M, Nygren H, Hyotylainen T, Ketola RA \& Kostiainen R 2013 Steroid and steroid glucuronide profiles in urine during pregnancy determined by liquid chromatography-electrospray ionization-tandem mass spectrometry. Analytica Chimica Acta 802 56-66. (https://doi.org/10.1016/j.aca.2013.09.034)

Joerger AC, Ang HC \& Fersht AR 2006 Structural basis for understanding oncogenic p53 mutations and designing rescue drugs. PNAS 103 15056-15061. (https://doi.org/10.1073/pnas.0607286103)

Kumar P, Henikoff S \& Ng PC 2009 Predicting the effects of coding non-synonymous variants on protein function using the SIFT algorithm. Nature Protocols 4 1073-1081. (https://doi.org/10.1038/ nprot.2009.86)

Li H \& Durbin R 2010 Fast and accurate long-read alignment with Burrows-Wheeler transform. Bioinformatics 26 589-595. (https://doi.org/10.1093/bioinformatics/btp698)

Liu X, Ory V, Chapman S, Yuan H, Albanese C, Kallakury B, Timofeeva OA, Nealon C, Dakic A, Simic V, et al. 2012 ROCK inhibitor and feeder cells induce the conditional reprogramming of epithelial cells. American Journal of Pathology 180 599-607. (https://doi.org/10.1016/j.ajpath.2011.10.036)

McKenna A, Hanna M, Banks E, Sivachenko A, Cibulskis K, Kernytsky A, Garimella K, Altshuler D, Gabriel S, Daly M, et al. 2010 The Genome Analysis Toolkit: a MapReduce framework for analyzing nextgeneration DNA sequencing data. Genome Research 20 1297-1303. (https://doi.org/10.1101/gr.107524.110)

Nanba K, Chen AX, Turcu AF \& Rainey WE 2016 H295R expression of melanocortin 2 receptor accessory protein results in ACTH responsiveness. Journal of Molecular Endocrinology 56 69-76. (https://doi.org/10.1530/JME-15-0230)

Pinto EM, Morton C, Rodriguez-Galindo C, McGregor L, Davidoff AM, Mercer K, Debelenko LV, Billups C, Ribeiro RC \& Zambetti GP 2013 Establishment and characterization of the first pediatric adrenocortical carcinoma xenograft model identifies topotecan as a potential chemotherapeutic agent. Clinical Cancer Research 19 1740-1747. (https://doi.org/10.1158/1078-0432.CCR-12-3354)

Pitts TM, Tan AC, Kulikowski GN, Tentler JJ, Brown AM, Flanigan SA, Leong S, Coldren CD, Hirsch FR, Varella-Garcia M, et al. 2010 Development of an integrated genomic classifier for a novel agent in colorectal cancer: approach to individualized therapy in early development. Clinical Cancer Research 16 3193-3204. (https://doi.org/10.1158/1078-0432.CCR-09-3191)

Quinkler M, Hahner S, Wortmann S, Johanssen S, Adam P, Ritter C, Strasburger C, Allolio B \& Fassnacht M 2008 Treatment of advanced adrenocortical carcinoma with erlotinib plus gemcitabine. Journal of Clinical Endocrinology and Metabolism 93 2057-2062. (https://doi.org/10.1210/jc.2007-2564)

Rainey WE, Saner K \& Schimmer BP 2004 Adrenocortical cell lines. Molecular and Cellular Endocrinology 228 23-38. (https://doi. org/10.1016/j.mce.2003.12.020)
(C) 2018 Society for Endocrinology Published by Bioscientifica Ltd. Printed in Great Britain 
Raymond VM, Everett JN, Furtado LV, Gustafson SL, Jungbluth CR, Gruber SB, Hammer GD, Stoffel EM, Greenson JK, Giordano TJ, et al. 2013 Adrenocortical carcinoma is a lynch syndrome-associated cancer. Journal of Clinical Oncology 31 3012-3018. (https://doi. org/10.1200/JCO.2012.48.0988)

Reid Y, Storts D, Riss T \& Minor L 2004 Authentication of human cell lines by STR DNA profiling analysis. In Assay Guidance Manual. Eds GS Sittampalam, NP Coussens, K Brimacombe, et al. Bethesda, MD, USA: NCBI. (available at: https://www.ncbi.nlm.nih.gov/books/NBK144066/)

Reva B, Antipin Y \& Sander C 2011 Predicting the functional impact of protein mutations: application to cancer genomics. Nucleic Acids Research 39 e118. (https://doi.org/10.1093/nar/gkr407)

Sbiera S, Schmull S, Assie G, Voelker HU, Kraus L, Beyer M, Ragazzon B, Beuschlein F, Willenberg HS, Hahner S, et al. 2010 High diagnostic and prognostic value of steroidogenic factor-1 expression in adrenal tumors. Journal of Clinical Endocrinology and Metabolism 95 E161-E171. (https://doi.org/10.1210/jc.2010-0653)

Schwarz JM, Cooper DN, Schuelke M \& Seelow D 2014 MutationTaster2: mutation prediction for the deep-sequencing age. Nature Methods 11 361-362. (https://doi.org/10.1038/nmeth.2890)

Seccia TM, Fassina A, Nussdorfer GG, Pessina AC \& Rossi GP 2005 Aldosterone-producing adrenocortical carcinoma: an unusual cause of Conn's syndrome with an ominous clinical course. EndocrineRelated Cancer 12 149-159. (https://doi.org/10.1677/erc.1.00867)

Takahashi K \& Yamanaka S 2006 Induction of pluripotent stem cells from mouse embryonic and adult fibroblast cultures by defined factors. Cell 126 663-676. (https://doi.org/10.1016/j.cell.2006.07.024)

Tentler JJ, Tan AC, Weekes CD, Jimeno A, Leong S, Pitts TM, Arcaroli JJ, Messersmith WA \& Eckhardt SG 2012 Patient-derived tumour xenografts as models for oncology drug development. Nature Reviews Clinical Oncology 9 338-350. (https://doi.org/10.1038/ nrclinonc.2012.61)

Terris B, Pineau P, Bregeaud L, Valla D, Belghiti J, Tiollais P, Degott C \& Dejean A 1999 Close correlation between beta-catenin gene alterations and nuclear accumulation of the protein in human hepatocellular carcinomas. Oncogene 18 6583-6588. (https://doi. org/10.1038/sj.onc.1203051)

Terzolo M, Angeli A, Fassnacht M, Daffara F, Tauchmanova L, Conton PA, Rossetto R, Buci L, Sperone P, Grossrubatscher E, et al. 2007 Adjuvant mitotane treatment for adrenocortical carcinoma. New England Journal of Medicine 356 2372-2380. (https://doi. org/10.1056/NEJMoa063360)

Trapnell C, Williams BA, Pertea G, Mortazavi A, Kwan G, van Baren MJ, Salzberg SL, Wold BJ \& Pachter L 2010 Transcript assembly and quantification by RNA-Seq reveals unannotated transcripts and isoform switching during cell differentiation. Nature Biotechnology 28 511-515. (https://doi.org/10.1038/nbt.1621)

Wang T \& Rainey WE 2012 Human adrenocortical carcinoma cell lines. Molecular and Cellular Endocrinology 351 58-65. (https://doi. org/10.1016/j.mce.2011.08.041)

Wang K, Li M \& Hakonarson H 2010 ANNOVAR: functional annotation of genetic variants from high-throughput sequencing data. Nucleic Acids Research 38 e164. (https://doi.org/10.1093/nar/gkq603)

Weigel B, Malempati S, Reid JM, Voss SD, Cho SY, Chen HX, Krailo M, Villaluna D, Adamson PC \& Blaney SM 2014 Phase 2 trial of cixutumumab in children, adolescents, and young adults with refractory solid tumors: a report from the Children's Oncology Group. Pediatric Blood and Cancer 61 452-456. (https://doi. org/10.1002/pbc.24605)

Wortmann S, Quinkler M, Ritter C, Kroiss M, Johanssen S, Hahner S, Allolio B \& Fassnacht M 2010 Bevacizumab plus capecitabine as a salvage therapy in advanced adrenocortical carcinoma. European Journal of Endocrinology 162 349-356. (https://doi.org/10.1530/EJE09-0804)

Young JA Jr, Ward KC \& Ries LAG 2007 Cancers of rare sites. In SEER Survival Monograph: Cancer Survival Among Adults: U.S. SEER Program, 1988-2001, Patient and Tumor Characteristics. National Cancer Institute, SEER Program. Pub. No. 07-6215. Eds J Young, LAG Ries, GE Keel et al. Bethesda, MD, USA: NIH.

Zehir A, Benayed R, Shah RH, Syed A, Middha S, Kim HR, Srinivasan P, Gao J, Chakravarty D, Devlin SM, et al. 2017 Mutational landscape of metastatic cancer revealed from prospective clinical sequencing of 10,000 patients. Nature Medicine 23 703-713. (https://doi. org/10.1038/nm.4333)

Zhao L, Bakke M \& Parker KL 2001 Pituitary-specific knockout of steroidogenic factor 1. Molecular and Cellular Endocrinology 185 27-32. (https://doi.org/10.1016/S0303-7207(01)00621-9)

Zhao C, Barner R, Vinh TN, McManus K, Dabbs D \& Vang R 2008 SF1 is a diagnostically useful immunohistochemical marker and comparable to other sex cord-stromal tumor markers for the differential diagnosis of ovarian sertoli cell tumor. International Journal of Gynecological Pathology 27 507-514. (https://doi. org/10.1097/PGP.0b013e31817c1b0a)

Zheng S, Cherniack AD, Dewal N, Moffitt RA, Danilova L, Murray BA, Lerario AM, Else T, Knijnenburg TA, Ciriello G, et al. 2016 Comprehensive pan-genomic characterization of adrenocortical carcinoma. Cancer Cell 29 723-736. (https://doi.org/10.1016/j. ccell.2016.04.002)

Received in final form 19 January 2018

Accepted 25 January 2018

Accepted Preprint published online 25 January 2018 http://erc.endocrinology-journals.org https://doi.org/10.1530/ERC-17-0447 (c) 2018 Society for Endocrinology Published by Bioscientifica Ltd. Printed in Great Britain 